\title{
A pilot study of MBA programmes in South Africa
}

\author{
Asphat Muposhi - Midlands State University, Zimbabwe \\ Manilall Dhurup - Vaal University of Technology, South Africa \\ Robert L. Martin - University of Venda, South Africa \\ Joyendu Bhadury* - Radford University, USA
}

\begin{abstract}
In recent years, Master of Business Administration (MBA) programmes and their curricula have been subjected to substantial scrutiny. However, the majority of studies have been confined to business schools in Western countries. By comparison, much less research is available on MBA programmes in developing countries, particularly those in Africa. In an effort to address this gap, this article examines MBA programmes in South Africa by first situating them within the global MBA curriculum debate. It then notes the need to move away from a generalist MBA programme to a specialized MBA in line with emerging global trends. Finally, it suggests a multidisciplinary approach to the redesign of the MBA curriculum.
\end{abstract}

Keywords: Master of Business Administration, curriculum, business schools, South Africa

\section{Introduction}

There is general consensus that the Master of Business Administration (MBA) is the flagship degree programme in the discipline of business and management education (Blackburn, 2011; Lundstrom, 2011; Rubin and Dierdorff, 2013). While precise data about the number of MBA degrees awarded around the world are not readily available, conservative estimates point to its scope (Temtime and Mmereki, 2011). For example, in the USA, which has approximately 1,000 business schools, figures available from the National Center for Education Statistics indicate that during the 2015/16 academic year, the latest year that such data are available, almost 200,000 masters degrees were awarded in business and management, with the overwhelming majority being MBAs, amounting to almost a quarter of all masters degrees awarded in the USA that year (Ginder et al., 2016). When this is viewed in light of the fact that there are over 16,000 schools worldwide granting business degrees, it points to the substantial number of MBA degrees being awarded each year (Lundstrom, 2011). In light of this international diversity of MBA programmes, it is unsurprising that there are various well-known accreditation agencies for them across the world, some more popular than others according to the region. For example, in the USA and Canada the most highly regarded accreditation is that by the Association to Advance Collegiate Schools of Business (AACSB). Another one is the Accreditation Council for Collegiate Business Schools and Programs, which is more popular among smaller institutions. Two other agencies are used by some business schools for accreditation purposes: the Council for Higher Education Accreditation is a non-governmental accreditation association whose span includes both business and non-business education, while the Distance 
Education Accrediting Commission focuses on online programmes. For business schools outside USA and Canada, accreditation is also available from the International Assembly for Collegiate Business Education. Specific to MBA programmes, additional accreditation agencies include: the Association of MBAs (AMBA) and the European Quality Improvement System (EQUIS); in particular, these last two are highly soughtafter accreditations outside the USA and Canada. Finally, individual countries may have their own accreditation standards and agencies for business schools and/or MBAs; for example, the Association of African Business Schools (AABS) is a soughtafter accreditation.

It is not surprising, therefore, that MBA programmes have also been the subject of much research conducted by business schools. Previous research efforts have mainly focused on the structure of the MBA curriculum (Thomas and Cornuel, 2012; Datar et al., 2010; Rubin and Dierdoff, 2009), the impact of MBA programmes (Kretovics, 1999; Bennis and O'Toole, 2005) and assessment (Cullen, 2013; Camuffo and Gerli, 2004). An obvious observation based on past studies is that most academic publications focus on MBA programmes in Western countries, especially the USA. This is unsurprising given that most world business schools are in these countries. Nonetheless, the past few decades have seen a substantial growth in the economies of developing countries and, concomitantly, the offering of business and management education therein. This has resulted in US business schools such as Duke University and Harvard Business Scholl, alongside those from the UK, such as Henley Business School and Edinburgh Business School, extending their operations to emerging markets such as South Africa (Baets, 2011).

Although the MBA programme has extended its footprint beyond Europe and other Western economies, the growth in academic literature on MBA programmes in non-European countries has not been commensurate. Among some of the few prominent works in Asian countries are MBA education in Japan by Ishida (1997), management perceptions of MBA graduates in Malaysia by Tay (2001) and the future of the MBA in China (Coffey and Wang, 2006; Haight and Kwong, 1999). As in Asia, the paucity of empirical studies on MBA programmes is mirrored in South Africa. Notable studies conducted thus far include an evaluation of the South African Model of MBA Accreditation (Blackmur, 2005, 2006), challenges faced by graduate business education in Southern Africa (Temtime and Mmereki, 2011) and management education for the 1990s (Hofmeyr, 1990). The fact that there are relatively few studies conducted on the MBA programme in South Africa clearly points to a need for more research. This article is an effort to address this research gap.

The remainder of the article is structured as follows. First, the MBA programme landscape in South Africa is discussed. The problem statement underpinning the study follows. Thereafter the methodology employed for data collection is elaborated. The article is completed by discussion of the results, implications of the study, its limitations and conclusions.

\section{MBA landscape in South Africa}

The history and growth of the South African MBA programme is situated in the history of apartheid and influenced by the country's colonial history. Given that South Africa was colonized primarily by European countries (the Netherlands and the UK), its educational system, including business and management elements, was strongly modelled on its European counterparts. During apartheid, business education was only offered by historically white universities and was primarily aimed at nurturing the 
business skills of white students (Singh et al., 2004). In 1949, the University of Pretoria became the first South African university to introduce the MBA programme (CHE, 2002). The period between 1990 to 2002 witnessed a remarkable growth: according to Singh et al. (2004), the number of MBA providers, which included both public and private institutions, increased from 7 to 37.

During the post-apartheid period, after 1994, there were far-reaching changes to the South African MBA programme. In 2002, the Council on Higher Education ( $\mathrm{CHE}$ ) commissioned a review of MBA programmes as well as the re-accreditation of institutions that were offering them (Blackmur, 2005). This review resulted in 15 institutions losing their accreditation; 15 being conditionally accredited; and seven gaining full accreditation (Blackmur, 2006). In addition, the CHE specified the core requirements of the mission statement of what should constitute a South African MBA programme, the teaching and learning pedagogy as well as the expected governance structures (ibid.). The CHE mission statement for the MBA programme compels institutions to provide a 'South African' programme that is aligned with the social and economic needs (Blackmur, 2005) of the country. As Singh et al. (2004) note, one of the key objectives of the reconceptualization of the MBA programme was to promote access and equity by developing the managerial competence of the previously marginalized non-white South Africans.

As of 2016, there were 17 accredited business schools offering the MBA programme in South Africa (Furlonger, 2017). Twelve of these business schools are owned by public higher education institutions, while five are privately owned. Of the 12, ten are managed by an Executive Dean, one (UFS Business School) is within a faculty of economics and management sciences, and the Gordon Institute of Business Science has a distinct name that separates it from its parent university (University of Pretoria) and has its own campus. A general MBA and Executive MBA are the two main types of programme offered in South Africa. When this study was conducted (MayAugust 2017), there were two specialized MBA programmes, MBA Tourism offered by MANCOSA and MBA Manufacturing offered by the Gordon Institute of Business Science. Other degrees that are comparable to the MBA in terms of curriculum are Master of Business Leadership, Master of Commerce Leadership and Master of Public Management. The Higher Education Quality Committee, an arm of the CHE, is mandated to evaluate the quality of MBAs every six years (Singh et al., 2004). The majority of business schools in South Africa are affiliated to the South African Business Schools Association (SABSA), AABS and AMBA. All MBA programmes in South Africa are accredited with the Higher Education Quality Council at National Qualification Framework Level 9.

\section{Problem statement}

In recent years, the MBA degree programme has been subjected to intense scrutiny (Prince et al., 2014; Busing and Palocsay, 2016; Schlegelmilch and Thomas, 2011). The criticisms levelled against the programme are many and multifaceted. One stream of criticism centres on its inability to develop business leaders who have the capacity to address contemporary business challenges (Busing and Palocsay, 2016; Schlegelmilch and Thomas, 2011). In what has been dubbed the 'knowing-doing' gap (Datar et al., 2010), business practitioners and scholars contend that there is a glaring gap between the skill set possessed by MBA graduates with those required by the workplace. For this reason, the MBA programme is criticized for failing to transform management into a profession (Schlegelmilch and Thomas, 2011). 
Another line of criticism is based on the perceived inadequacy of MBA programmes in nurturing ethical leadership. For instance, corporate scandals and ethical dilemmas at BP, WorldCom, Barclays and Enron, among others, were partly attributed to the failure by business schools to produce ethical leaders (Enrich and Muñoz, 2011). Following the global financial crisis in 2007-8, part of the blame was apportioned to business schools and, in particular, to MBA programmes (Thomas and Cornuel, 2012; Langmead et al., 2010). With the escalating growth in corporate scandals and ethical dilemmas, the MBA curriculum has been vilified (Gruber and Schlegelmilch, 2013). In particular, it has been blamed for trading sound business principles in favour of maximizing shareholder value (Schlegelmilch and Thomas, 2011).

Global concerns about the relevance of the MBA programme are mirrored in South Africa. For instance, Baets (2011) questions whether South African MBA programmes that are grounded in the European business model are relevant to the African context. Collectively, the perceived shortcomings of the MBA programme have resulted in calls for the reinvention of the curricula (Thomas and Cornuel, 2012). It is against this background that this study attempts to examine the characteristics of MBA programmes in South Africa, intending to critically examine their locus standi within the global MBA discourse, with a special focus on curricular content. One core research question has guided the study - what are the characteristics of South African MBA programmes as viewed from the standpoint of their curricula? By addressing this question, we seek to contribute to ongoing efforts to recalibrate the MBA curriculum.

\section{Research methodology}

The data collection for this study was performed in May-August 2017. Document analysis was employed as the main method, complemented by a questionnaire survey. Consistent with the tenets of document analysis, documents of business schools related to the MBA programme were identified as the research field. As noted by Owen (2014), documents are outcomes of collective engagement, and hence have the potential to provide a rich data set. Furthermore, based on Owen's (2014) assertion that 'a university is in its documents rather than its buildings', this study is of the view that the identity of the MBA programme resides in its documentation. The theoretical lens that formed the basis of document analysis was derived from the attributes used for MBA rankings by the Financial Times and Eduniversal. Selected attributes that were analysed include mission statements of business schools, outcomes of the MBA programme, accreditations and affiliations, research, curricula, funding, student profile, mode of delivery and assessment criteria. The SABSA membership listing of 17 business schools was used as a sample frame.

Given the focus of this study on MBA curricula and their relationship with the school mission, the primary source of data was document analysis, which considered all the 17 accredited business schools. This document analysis involved a detailed process of gleaning through the web pages, catalogues and brochures of different MBA programmes in order to identify their features, attributes and curriculum content. Document analysis was also done in order to delineate overall commonalities and attributes of MBA programmes in South Africa. A structured questionnaire survey was administered to senior administrators from both public and private institutions offering the MBA programme in South Africa (Appendix 1). Given the nature of the questions (related to accreditation and modality), it was deemed that senior administrators would be best equipped to provide the information sought. A total of 17 questionnaires were distributed and six were returned for analysis, four from business schools under public 
universities and two from privately owned business schools. This low response rate was deemed adequate given the sensitive nature of the study and the discontinuation of some MBA programmes during the 2004 audit. The data collected from six schools was used to complement and reinforce the data collected through document analysis.

\section{Data analysis}

Data from document analysis was analysed using principles of interpretivism in form of content analysis and following a three-step procedure of thematic content analysis suggested by Strauss and Corbin (1990). Following this approach, subthemes and subcategories that emerged from documentary analysis were integrated to form substantive themes. Simple tabulation was used to analyse the data generated from questionnaires. The next section presents the results of the study.

\section{Presentation of results}

This section presents the results of document and questionnaire analysis. It focuses on the profile of business schools in South Africa in terms of mission statements, rankings, funding model, student profile, curriculum, membership, partnerships and affiliations. Tables 1 to 9, which all appear in Appendix 2 at the end of this article, provide the institutional metrics.

The mission statement of a business school defines its strategic thrust and the identity of its qualification matrix (Bevelander et al., 2015; Rubin and Dierdorff, 2009). In particular, the CHE (2004) directs that the mission statement of the MBA programme needs to meet specific regulated core specifications in terms of purpose, teaching pedagogy, research and governance. Consistent with the CHE requirements, the majority of the mission statements of the MBA programmes in South Africa revolve around leadership, research and community engagement. Table 1 provides a snapshot of selected mission statements of six prominent MBA business schools in South Africa. In order to direct their MBA programmes towards specific goals, some of the business schools in South Africa publish outcomes, as shown in Table 2. Table 3 presents institutional data for business schools in the sample.

The South African MBA programme has a global outlook, as shown by international membership and affiliations. It is important to state that when this study was conducted some of the MBA providers were in the process of applying for accreditation with $A A B S, A M B A$ and other bodies. It may be possible that such business schools may have attained accreditation after the data collection process. Table 4 provides regional and international memberships, accreditations and affiliations.

In addition to affiliations and memberships, some business schools have partnerships with international organizations. Wits Business School has an association with Partnership in International Management, Graduate School of Business (UCT) is a partner of the Eduniversal World Convention and Gordon Institute of Business Science has partnerships with Harvard Business School, which delivers its Annual Senior Executive Program, and Toyota Wessels Institute for Manufacturing Studies, which delivers its manufacturing-orientated MBA programme. UCT Global Network for Advanced Management gives local students opportunities to study abroad. It also partners with international business schools, such as Indian Institute of Management Ahmedabad, Warsaw School of Economics and Copenhagen Business School, among others, for its exchange programme. Business schools in South Africa are also expanding their qualification mix, as shown in Table 5. 
The South African MBA programme follows a blended mode of lecture delivery, which includes full-time, part-time, modular, block release and distance teaching (Furlonger, 2017). The modes of lecture delivery are summarized in Table 6.

The MBA curriculum in South Africa consists of core modules that are compulsory for all students and electives. Table 7 summarizes these core modules, derived from prospectuses and web pages. The percentage represents the number of business schools offering the core module. For instance, 100 per cent for strategic marketing management indicates that the module is offered by all 17 business schools considered in this study. In the context of South African business schools, electives (optional modules) are perceived as specializations. In Table 8, electives offered are outlined.

Some business schools have resource centres that provide a comprehensive source of information, data and expertise on specific topics. Table 9 provides a list of resources and their focus areas.

\section{Discussion of results}

The business schools in South Africa are generally competitive, as shown by accreditations to international bodies as well as regional and international rankings. Investment in international partnerships and collaborations, coupled with establishment of resource centres dedicated to nurture creativity and problem-solving skills, are noteworthy. Despite this, there are pertinent issues that need to be addressed in order to position South African business schools in an increasingly competitive environment.

\section{Challenges of a mandated MBA mission statement}

A mandated mission statement of the South African MBA programme, though necessary to align the qualification with the developmental ethos of the government, has resulted in a homogeneity of the programme. Additionally, with corporatization, marketization and internalization increasingly evident in management education, this limits the flexibility of business schools in aligning the MBA programme with the ever-changing business environment. However, it is also important to note the rational grounds of the CHE's approach in specifying mission statements for the MBA programme. As Wilson and Thomas (2012) note, a significant number of MBA programmes are facing an identity crisis, coupled with a blurred concept of their societal contribution. Although the identity of the MBA programme is clearly articulated for European and Western economies (Brailsford, 2011), the same may not be said with respect to an African MBA programme. So in this context, by specifying the core requirements of the mission statement of the MBA programme, it may be argued that the CHE's intention was to develop an MBA programme with an African identity. This view gains support from Baets (2011), who cautions against importing European business school models to South Africa as they fail to consider the contextual realities of the country. Without this oversight, Pfeffer and Fong (2002) contend that business schools tend to be driven primarily by market needs rather than societal ones.

\section{The model of business schools in South Africa}

The other important finding relates to the model of business schools in South Africa. The majority of business schools operate as a unit within a parent university. Although this model allows business schools to piggyback on the reputation of the parent university, it has inherent weaknesses. For instance, it is reasonable to speculate that the reputation of the University of Cape Town's Graduate School of Business was dented by 2016 fees 
protests at its parent institution. It could be one of the reasons why it failed to appear in the 2017 Top 100 Financial Times rankings. Moreover, a business school following this model lacks distinctiveness in terms of brand and autonomy in decision-making. According to Rubin and Dierdorff (2009), an independent business school can use its own institutional and intellectual capital to differentiate itself in the marketplace. The success of the London Business School, SLOAN School of Management and Peru's CENTRUM Catolica is partly attributed to their autonomy.

\section{Sustainability of models of delivery and access}

The sustainability of the modes of lecture delivery predominately used by business schools in South Africa (full time, part time and modular) is another concern. These modes of delivery are resource intensive in terms of faculty administration. In the context of dwindling sources of funding, business schools in South Africa should learn from Milpark Business School's online MBA programme. The trend towards virtual universities is now a reality, so the opportunities presented by the growth in information and communications technology should be tapped into. In this regard, IE Business School (Global MBA), Lorange Institute of Business and Norwegian School of Management should be acclaimed for their virtual model that employs a part-time network of leading scholars. This reduces the red tape associated with faculty-based business schools. Also emanating from the study are concerns that the MBA programme in South Africa remains market driven and elitist, thereby limiting access to management education. The rising of MBA admission requirements, though consistent with international standards, coupled with premium fees make the programme inaccessible for the low end of the market (informal sector employees and emerging entrepreneurs). Therefore, based on Thomas and Cornuel (2012), the MBA programme in South Africa needs to be aligned to societal needs and aspirations.

\section{Need for a research-orientated faculty}

Another peculiar feature of the South African MBA curriculum is the compulsory research module that is directed by the CHE (Blackmur, 2005). As part of CHE's regulatory framework, research modules should contribute about 25 per cent to the overall weight of the MBA programme (CHE 2004). Although the value of evidencebased decision-making is widely acknowledged, it is the value of such research output that has generated considerable debate (Blackmur, 2006). For instance, Barley et al. (1988) notes that the MBA curriculum-based research, which often takes the form of research methodology and research thesis modules, is not always aligned to business challenges. Research should also be used as an income stream for business schools. Although some institutions, such as University of Stellenbosch Business School, support renowned journals, other business schools are lagging behind. The Harvard Business School provides a benchmark in this sense, with its financing model disseminating research produced by the faculty through its publishing unit. In 2009, Harvard Business School generated 29 per cent of its revenue from publications such as the Harvard Business Review.

\section{Curriculum specifics of South African MBA programmes}

With the exceptions of MANCOSA's MBA Tourism, University of Stellenbosch Business School's MBA specializing in manufacturing and Rhodes Business School MBA specializing in sustainable ocean resources, MBAs are general in their scope. This is despite the fact that the title of general manager is now archaic in most companies. 
Furthermore, as shown in Table 7, the South African MBA curriculum is skewed towards functional and analytical skills. According to Schlegelmilch and Thomas (2011), such an overemphasis on functional and analytical skills is not adequate for developing market-orientated managers. In the same vein, Navarro (2008) cautions that an MBA programme predominantly centred on functional aspects of business has an inherent danger of entrenching a 'silo' managerial mindset; this potentially limits managers in their understanding of the essence of synergies across business functions. Although analytical skills play a critical role in equipping managers with problem-solving capacity, Schoemaker (2008) argues that most MBA analytical modules are based on case studies and scenarios that often do not replicate real business settings.

It is also evident that safeguarding shareholder value is the most important curricular objective of South African MBA programmes. As indicated in Table 7, all business schools offer management accounting and finance as a core module. In contrast, core modules with a stakeholder or community orientation such as social responsibility are only offered by 50 per cent of business schools. According to Ghosal (2005), by prioritizing the maximization of shareholder value, business schools have the potential of developing managers guided mainly by the profit motive.

Another area of concern within the South African MBA curriculum is the peripheral recognition accorded to entrepreneurship. For instance, only three business schools out of 17 (18 per cent) offer entrepreneurship as a core module, while others offer it as an elective, and in four business schools it is not included in the module structure. This is despite the fact that the majority of MBA students indicate their willingness to start their own businesses upon completion (Furlonger, 2017), as well as the contribution of entrepreneurship in fostering economic growth (Stewart and Pepper, 2011). The peripheral recognition of entrepreneurship in business education is reflected by a high failure of small and medium-sized enterprises in South Africa, which is estimated at 70 per cent.

Another aspect of business education that is given relatively low prominence in the South African MBA programme is ethics. As shown in Table 7, only 50 per cent of business schools offer ethics as a core module, while others offer it as an elective. Even if ethics is selected as an elective, its delivery depends on the viability of the class. Ethics education is pertinent especially in South Africa, which has witnessed a fair number of ethical dilemmas and corporate scandals, examples being Eskom and SABC, and the scourge of corruption in government municipalities. Given that many of these scandals involved business leaders as well as public and elected administrators, it is imperative that business ethics be covered in MBA curricula. The importance of ethics is shared by Langmead et al. (2010), who recommend more emphasis on the subject in the MBA curriculum in order to avoid the recurrence of the global financial crisis, which was characterized by glaring lapses in ethical oversight. This recommendation gains support from McTiernan and Flynn (2011), who argue that ethical education as opposed to regulation is a potential long-term solution to unethical business practices. Sound ethical behaviour, as Jackson (2006) notes, has the added advantage of improving the reputation of an organization and also has a pull effect on investors.

Apart from ethics, as shown in Table 7, there is also a low representation of soft skills in the South African MBA curriculum for the majority of MBA business schools. A majority of soft skills-orientated modules are offered as electives, and if they are not opted for by students this ultimately results in MBA graduates with a soft skills deficit. As indicated in Table 3, only two business schools out of 17 (12 per cent) offer business communication as a core module. This is a pertinent concern in view of the observation by May et al. (2012) that a significant number of MBA graduates are unable 
to communicate and write effectively. Of major concern also is that major soft skill modules such as interpersonal skills, negotiations and team-building are not included in the majority of the MBA core curriculum in South Africa. This is despite the fact that such modules, as pointed out by Benjamin and O'Reilly (2011), are critical for enhancing management effectiveness.

Finally, the original CHE intention to develop an MBA programme with an African identity appears to be missing when measured against the curricula of the business schools depicted in Table 7. Instead, the topics seem to be orientated more towards corporate and business needs and less towards societal and community concerns, such as environmental sustainability, ethical and moral decision-making. Although some business schools have started including Africanization under the concept of internationalization, none seem to have a specific focus on a programme that will enhance the development and understanding of African relationships (between different African countries). This issue is especially important because there are substantial differences between African countries with regard to economic development and cultural norms. In light of the fact that several South African companies have started to operate in different African countries, there is a sufficient rationale to make the development and understanding of African relationships a core subject of a South African MBA.

\section{Global mindedness}

Although South African business schools have an estimated 251 formal agreements with other business schools in other countries in terms of student and lecturer exchanges, international study tours, and academic and research collaborations (Furlonger, 2017), Table 7 shows that the South African MBA programme has a limited global orientation. Almost 50 per cent of the core curriculum does not have a global economy-orientated module. Although South Africa is a key member of emerging markets under the auspices of the BRICS countries (Brazil, Russia, India, China and South Africa), only two business schools out of 17 (12 per cent) offer emerging markets as a core module. Apart from the global curriculum orientation, only about 40 per cent of South African business schools are affiliated to prestigious international MBA bodies such as AMBA and the AACSB. This could be a plausible reason why, in 2016, South African MBA business schools only managed to enrol 139 non-African students (Furlonger, 2017). Overall, the limited global orientation negatively influences the global market appeal of the South African MBA programme. To enhance their international footprint, South African business schools may also consider penetrating regional or international markets. To this end, Insead Business School's growth strategy in France and Singapore could be used as a case study.

\section{Teaching and learning pedagogy}

A review of the prospectus and websites of business schools in South Africa shows that the main teaching and learning method is the case study approach. This was recommended by the CHE's (2004) review of the MBA programme. According to CHE (2004), such case studies need to be aligned to the South African context. However, critics of case study-based learning such as Blackmur (2005) argue that a mix of teaching pedagogy is imperative in view of the multidisciplinary nature of the MBA programme. Arguing against a 'one size fits all' teaching pedagogy, Rubin and Dierdorff (2013) are of the view that teaching pedagogy needs to be informed by the learning outcomes of the module as opposed to business school traditions. For instance, behavioural 
modelling seminars as opposed to case studies are considered effective in teaching soft skills (Taylor et al., 2005).

\section{Tyranny of MBA rankings}

Consistent with the global trend, South African business schools are also engaged in what Corley and Gioia (2000: 320) call 'playing the rankings game'. An examination of web pages, prospectuses and other promotional material for South African business schools indicate that rankings are highly publicized. Although these play a critical role for prospective students and recruiters, Rubin and Dierdorff (2013) caution against the tendency of diverting resources earmarked for teaching and learning to enhance market standing. In addition, noting the subjective nature of rankings, Morgeson and Nahrgang (2008) argue that a good ranking does not always imply a good curriculum or high-quality graduates. Another concern is the proliferation of MBA rankings that employ different rating criteria, something that has the potential to confuse users. For instance, in South Africa the Financial Times Executive MBA Rankings, Eduniversal Global Rankings of Executive MBA Degrees and $3^{\text {rd }}$ League of the 1000 Best Business Schools rank MBA programmes using a set of varied benchmarks. As these rankings proliferate, there is likely to be more confusion for prospective students. Although rankings are increasingly used by employers for recruitment purposes, Thomas and Cornuel (2012) argue that a predominant focus on rankings may entice business schools to direct more marketing resources towards this aspect at the expense of investment in infrastructure and faculty development.

\section{Implications of the study}

This study has important implications for business schools in South Africa and the CHE that regulates the MBA programme. First, the study indicates that the mission statement of the South African MBA programme is centred on the general management model. There is a need for business schools in consultation with CHE to broaden this mission statement in line with the global trend towards specialized MBAs. Secondly, the study points to the need by South African business schools to enhance the global orientation of their MBA programmes as well as the proportion of core modules focused on soft skills. Thirdly, in terms of the recalibration of the MBA curriculum, there is a need to move away from a functional and analytical skillsskewed MBA curriculum by including ethics, environmental sustainability and globalorientated modules. Failure to renew the MBA curriculum may result in student flight, as value for money is becoming a critical criteria in selection of a business school. Furthermore, the growing influence of globalization, as epitomized by global competition, global sourcing and global financing, underscores the need for South African business schools to groom and nurture future managers with a global mindset. In order to grow their global influence, South African businesses need to continue to invest in symbiotic partnerships and collaborations underpinned by trust.

\section{Conclusions, limitations and future research}

This article has examined the features, attributes and characteristics of the South African MBA programme. It suggests the need to restructure the South African MBA curriculum. The study also emphasizes the need to broaden the CHE-regulated mission statement of the South African MBA programme. From a curriculum standpoint, the study highlights the need to improve the core curriculum of the MBA with modules 
that focus on a global perspective and soft skills. The dynamic nature of today's business environment points to the need to continuously realign the curriculum with emerging business trends. Such a market orientation approach to curriculum review has the potential of enhancing the global competitiveness of the South African MBA programme. In order to develop an MBA curriculum that is aligned to the South African context, there is a need to consider the level of economic development, political ideology and nature of the educational system. The South African MBA regulators also need to consider, in line with global trends, a specialized MBA programme that goes beyond the general management model.

This study has inherent limitations that are worth noting. First, it partly relies on data collected from web pages and other MBA promotional material such as prospectuses and pamphlets. It is possible that some of the information used may have changed but has not yet been updated in the promotional material. Second, the article assesses curriculums based on content rather than learning outcomes and the degree to which each programme successfully attained them - this could be the focus of a future study that would involve more significant direct data collection from individual programmes. Another limitation of this pilot study is that it has not identified challenges faced by MBA programmes and impediments to programme development; once again, we believe that this ought to be a future course of study. Moreover, future studies may employ a more holistic approach that also includes the views of employers and MBA graduates. Such an approach may prove useful in understanding the competencies of MBA graduates from an employer perspective as well as the learning experience of students. It is important to note that the future studies we propose will require substantially more direct data collection from different stakeholders (employers, faculty, students and administrators) than our current study. Lastly, the study has been confined to the South African MBA programme. In order to delineate likely gaps in this curriculum, future studies may conduct a comparative study with MBA programmes in other countries.

\section{Notes on the contributors}

Asphat Muposhi has research interests in management education, green marketing and sustainable consumption. He completed his PhD at Vaal University of Technology in South Africa, and is currently a lecturer at Midlands State University, Zimbabwe.

Manilall Dhurup is currently the Acting Deputy Vice Chancellor: Resources and Planning at Vaal University of Technology (VUT), South Africa. He still maintains the position of Executive Dean of Faculty of Management Sciences at VUT. He holds a $\mathrm{PhD}$ in Marketing and has published widely in national and international journals. His research interest is in marketing and e-marketing.

Robert Martin is currently Deputy Vice Chancellor Operations at the University of Venda, South Africa. His previous position was Acting DVC Governance, Operations and Transformation and Executive Director Strategic Alliances, at Vaal University of Technology. Dr Martin holds a PhD in Entrepreneurship and his research interests are in entrepreneurship, small business development, strategic planning, management and e-learning.

Joyendu Bhadury is the Dean of the Davis College of Business and Economics at Radford University, Virginia, USA, prior to which he was the Dean of the School of Business and Management at SUNY-Brockport. He holds a PhD in Management Science from the University of Texas at Dallas. His professional specialization is in 
Operations and Supply Chain Management, and he has published widely in national and international academic journals.

\section{References}

Baets, Walter (2011) 'Africa needs a new business school model'. Financial Times, 3 April. Online. https://www.ft.com/content/f1c30ebc-5c69-11e0-8f48-00144feab49a (accessed 2 September 2019).

Barley, S.R., Meyer, G.W. and Gash, D.C. (1988) 'Cultures of culture: Academics, practitioners and the pragmatics of normative control'. Administrative Science Quarterly, 33 (1), 24-60.

Benjamin, B. and O'Reilly, C. (2011) 'Becoming a leader: Early career challenges faced by MBA graduates'. Academy of Management Learning \& Education, 10 (3), 452-72.

Bennis, W.G. and O'Toole, J. (2005) 'How business schools lost their way'. Harvard Business Review, 83 (5), 96-104.

Bevelander, D.L., Page, M.J., Pitt, L.F. and Parent, M. (2015) 'On a mission: Achieving distinction as a business school?' South African Journal of Business Management, 46 (2), $29-41$.

Blackburn, G. (2011) 'Which Master of Business Administration (MBA)? Factors influencing prospective students' choice of MBA programme - an empirical study'. Journal of Higher Education Policy and Management, 33 (5), 473-83.

Blackmur, D. (2005) 'An evaluation of the South African model of MBA accreditation'. Quality in Higher Education, 11 (2), 87-102.

Blackmur, D. (2006) 'The South African MBA review and the principles of efficient regulation'. Quality in Higher Education, 12 (1), 81-93.

Brailsford, T. (2011) Business Education in the Asia-Pacific: Contexts and Challenges. St. Lucia: University of Queensland Press.

Busing, M.E. and Palocsay, S.W. (2016) 'Operations management in the design and execution of MBA programs'. Journal of Education for Business, 91 (2), 75-82.

Camuffo, A. and Gerli, F. (2004) 'An integrated competency-based approach to management education: An Italian MBA case study'. International Journal of Training and Development, 8 (4), 240-57.

CHE (Council on Higher Education) (2002) 'National Plan for Higher Education in South Africa'. Ministry of Education. Online. http://www.justice.gov.za/commissions/FeesHET/docs/2001NationalPlanForHigherEducation.pdf (accessed 2 September 2019).

CHE (Council on Higher Education) (2004) 'South African education in the first decade of democracy'. Pretoria: Council on Higher Education.

Coffey, B.S. and Wang, J. (2006) 'Service learning in a Master of Business Administration (MBA) integrative project course: An experience in China'. Journal of Education for Business, $82(2), 119-24$

Corley, K. and Gioia, D. (2000) 'The rankings game: Managing business school reputation'. Corporate Reputation Review, 4, 319-33.

Cullen, A. (2013) 'Using the case method to introduce information skill development in the MBA curriculum'. Journal of Business and Finance Librarianship, 18 (3), 208-32.

Datar, S.M., Garvin, D.A. and Cullen, P.G. (2010) Rethinking the MBA: Business education at a crossroads. Boston: Harvard Business Press.

Enrich, D. and Schaefer Muñoz, S. (2011) 'Few Banks Fail EU Exams', The Wall Street Journal, Business, Saturday 16 July.

Furlonger, D. (2017) 'The South African Business School Environment'. In Durand, T. and Dameron, S. (eds), The Future of Management Education-Volume 1: Challenges Facing Business Schools Around the World. London: Palgrave Macmillan, pp. 277-82.

Ghosal, S. (2005) 'Bad management theories are destroying good management practices'. Academy of Management Learning \& Education, 4 (1), 75-91.

Ginder, S.A., Kelly-Reid, J.E. and Mann, F.B. (2016) Postsecondary Institutions and Cost of Attendance in 2015-16; Degrees and Other Awards Conferred, 2014-15; and 12-Month Enrollment, 2014-15: First Look (Provisional Data) (NCES 2016-112rev). Washington, DC: National Center for Education Statistics. Online. https://nces.ed.gov/pubs2016/2016112rev.pdf (accessed 8 August 2019).

Gruber, V. and Schlegelmilch, B.B. (2013) 'Integration and exchange: How Executive MBA students envision ethics education'. Journal of Marketing Education, 35 (2), 95-106.

Haight, G.T. and Kwong, K.K. (1999) 'Future of the MBA in China'. Business Forum, 24 (1-2), 33. 
Hofmeyr, K.B. (1990) 'Management education for the nineties'. South African Journal of Business Management, 21 (3), 102-11.

Ishida, H. (1997) 'MBA education in Japan: The experience of management education at the Graduate School of Business Administration, Keio University, Japan'. Journal of Management Development, 16 (3), 185-96.

Jackson, J. (2006) Ethics in Medicine: Virtue, Vice and Medicine. Cambridge: Polity.

Kretovics, M.A. (1999) 'Assessing the MBA: What do our students learn?'. Journal of Management Development, 18 (2), 125-36.

Langmead, J.M., Sedaghat, A.M. and Unger, M.L. (2010) 'Incorporating international accounting into the MBA curriculum: Exploring implications of the financial reporting crisis of 2001-2009'. Journal of Teaching in International Business, 21 (2), 132-52.

Lundstrom, W.J. (2011) 'MBA attitudes toward business: What we don't know can hurt us or help us'. Journal of Education for Business, 86 (3), 178-85.

May, G.L., Thompson, M.A. and Hebblethwaite, J. (2012) 'A process for assessing and improving business writing at the MBA level'. Business Communication Quarterly, 75 (3), 252-70.

McTiernan, S. and Flynn, P.M. (2011) "'Perfect Storm" on the horizon for women business school deans?'. Academy of Management Learning \& Education, 10 (2), 323-39.

Morgeson, F.P. and Nahrgang, J.D. (2008) 'Same as it ever was: Recognizing stability in the BusinessWeek rankings'. Academy of Management Learning \& Education, 7 (1), 26-41.

Navarro, P. (2008) 'The MBA core curricula of top-ranked US business schools: A study in failure?'. Academy of Management Learning and Education, 7 (1), 108-23.

Owen, G.T. (2014) 'Qualitative methods in higher education policy analysis: Using interviews and document analysis'. The Qualitative Report, 19 (26), 1-19.

Pfeffer, J. and Fong, C.T. (2002) 'The end of business schools? Less success than meets the eye'. Academy of Management Learning and Education, 1 (1), 78-95.

Prince, M., Burns, D.J. and Manolis, C. (2014) 'The effects of part-time MBA programs on students: The relationships between students and their employers'. Journal of Education for Business, 89 (6), 300-9.

Rubin, R.S. and Dierdorff, E.C. (2009) 'How relevant is the MBA? Assessing the alignment of required curricula and required managerial competencies'. Academy of Management Learning and Education, 8 (2), 208-24.

Rubin, R.S. and Dierdorff, E.C. (2013) 'Building a better MBA: From a decade of critique toward a decennium of creation'. Academy of Management Learning and Education, 12 (1), 125-41.

SABSA (2012) South African Business Schools Association. Online. http://www.sabsa.co.za/ (accessed 10 September 2019).

SABSA (2015) South African Business Schools Association. Online. http://www.sabsa.co.za/ (accessed 10 September 2019).

Schlegelmilch, B.B. and Thomas, H. (2011) 'The MBA in 2020: Will there still be one?'. Journal of Management Development, 30 (5), 474-82.

Schoemaker, P.J. (2008) 'The future challenges of business: Rethinking management education'. California Management Review, 50 (3), 119-39

Singh, M., Lange, L. and Naidoo, P. (2004) 'Evaluating the MBA in South Africa'. Quality in Higher Education, 10 (3), 197-206.

Stewart, D. and Pepper, M.B. (2011) 'Close encounters: Lessons from an indigenous MBA program'. Journal of Management Education, 35 (1), 66-83.

Strauss, A. and Corbin, J. (1990) Basics of Qualitative Research. London: SAGE.

Tay, A. (2001) 'Management's perception of MBA graduates in Malaysia'. Journal of Management Development, 20 (3), 258-74.

Taylor, P.J., Russ-Eft, D.F. and Chan, D.W. (2005) 'A meta-analytic review of behavior modeling training'. Journal of Applied Psychology, 90 (4), 692.

Temtime, Z.T. and Mmereki, R.N. (2011) 'Challenges faced by graduate business education in Southern Africa: Perceptions of MBA participants'. Quality Assurance in Education, 19 (2), 110-29.

Thomas, H. and Cornuel, E. (2012) 'Business schools in transition? Issues of impact, legitimacy, capabilities and re-invention'. Journal of Management Development, 31 (4), 329-35.

Wilson, D.C. and Thomas, H. (2012) 'The legitimacy of the business of business schools: what's the future?' Journal of Management Development, 31 (4), 368-76. 


\section{Appendix 1 - Survey questionnaire for 'A pilot study of MBA programs in South Africa'}

\section{Introduction:}

The purpose of this survey is to understand the landscape of MBA programmes in South Africa including the rationale, focus, learning outcomes, instructional methodology and target market of such programmes. The information collected in this survey is general and will not be used for the purposes of identifying specific programmes and/or institutions.

\section{Section A: Demographic Information}

In this section we would like to find out more about the demographic profile of your MBA program. Please place a cross (X) in the appropriate block.

\begin{tabular}{|l|l|l|l|l|l|l|}
\hline A1 & $\begin{array}{l}\text { Number of years your institution has been offering } \\
\text { the MBA? }\end{array}$ & $1-5$ & $6-10$ & $11-15$ & $16-20$ & $20+$ \\
\hline
\end{tabular}

\begin{tabular}{|l|l|l|l|}
\hline A2 & Is the MBA program within your institution under & Business school & University faculty \\
\hline
\end{tabular} a Business School or within a University faculty?

\begin{tabular}{|l|l|l|l|l|}
\hline A3 & Is the Business school & Independently managed? & Self-funded? & University funded? \\
\hline
\end{tabular}

\begin{tabular}{|l|l|l|l|l|}
\hline A4 & Mode of delivery & Full-time contact & Part-time & Distance learning \\
\hline
\end{tabular}

\begin{tabular}{|l|l|l|l|}
\hline A5 & Membership of a business association & Yes & No \\
\hline
\end{tabular}

\begin{tabular}{|l|l|l|l|l|l|}
\hline A6 & $\begin{array}{l}\text { Percentage of MBA academic staff } \\
\text { who are }\end{array}$ & Full-time & Part-time & $\begin{array}{l}\text { From } \\
\text { industry }\end{array}$ & $\begin{array}{l}\text { From other } \\
\text { institutions }\end{array}$ \\
\cline { 4 - 6 } & & $\ldots \ldots \%$ & $\ldots \ldots \%$ & $\ldots \ldots \ldots \%$ & $\ldots \ldots \ldots \ldots \%$ \\
\hline
\end{tabular}

\begin{tabular}{|l|l|l|l|l|}
\hline A7 & $\begin{array}{l}\text { Primary target group of your MBA } \\
\text { program }\end{array}$ & Managers & Mainstream students & Entrepreneurs \\
\hline
\end{tabular}

\begin{tabular}{|l|l|l|l|l|l|}
\hline A8 & Type of your MBA program & Full-time & Part-time & Modular MBA & Executive MBA \\
\hline
\end{tabular}

\section{Section B: The MBA academic profile:}

In this section we would like to find out more about the academic profile of your MBA program. Please place a cross $(\mathbf{X})$ in the appropriate block.

\begin{tabular}{|l|l|l|l|}
\hline B1 & $\begin{array}{l}\text { Do you have other Universities (not Business Schools) within the } \\
\text { country? }\end{array}$ & Yes & No \\
\hline
\end{tabular}

Please complete the following table if you answered (Yes) in B1.

\begin{tabular}{|l|l|l|}
\hline \multicolumn{2}{|l|}{ Question } & Answer (\%) \\
\hline B2 & $\begin{array}{l}\text { What percentage of your academic staff falls within this category, } \\
\text { i.e., teach at this location? }\end{array}$ & \\
\hline B3 & What subjects do they teach at this location? & \\
\hline B4 & $\begin{array}{l}\text { How are they utilized e.g. regular time table, blocks, etc. at this } \\
\text { location? }\end{array}$ & \\
\hline
\end{tabular}


B5 Does your institution/business School have other locations inside or outside the country?

Please complete the following table if you answered (Yes) in B5.

\begin{tabular}{|l|l|l|}
\hline \multicolumn{2}{|l|}{ Question } & Answer (\%) \\
\hline B6 & $\begin{array}{l}\text { What percentage of your academic staff falls within this category, } \\
\text { i.e., teaches at other business school locations within the country? }\end{array}$ & \\
\hline B7 & What subjects do they teach? & \\
\hline B8 & How are they utilized e.g. regular time table, blocks, etc.? & \\
\hline
\end{tabular}

\begin{tabular}{|l|l|l|l|}
\hline B9 & Universities (not Business Schools) outside the country? & Yes & No \\
\hline
\end{tabular}

Please complete the following table if you answered (Yes) in B9.

\begin{tabular}{|l|l|l|}
\hline \multicolumn{2}{|l|}{ Question } & Answer (\%) \\
\hline B10 & What percentage of your academic staff falls within this category? & \\
\hline B11 & What subjects do they teach? & \\
\hline B12 & How are they utilized e.g. regular time table, blocks, etc.? & \\
\hline
\end{tabular}

\begin{tabular}{|l|l|l|l|}
\hline B13 & Do Business Schools from outside the country offer programmes at & Yes
\end{tabular} your institution?

Please complete the following table if you answered (Yes) in B13.

\begin{tabular}{|c|c|c|c|}
\hline \multicolumn{2}{|c|}{ Question } & \multicolumn{2}{|c|}{ Answer (\%) } \\
\hline B14 & $\begin{array}{l}\text { What percentage of your academic staff falls within this category, } \\
\text { i.e., teach for other business schools outside the country? }\end{array}$ & & \\
\hline B15 & What subjects do they teach? & & \\
\hline B16 & How are they utilized e.g. regular time table, blocks, etc.? & & \\
\hline B17 & $\begin{array}{l}\text { Does your business school offer programmes from companies } \\
\text { within the country? }\end{array}$ & Yes & No \\
\hline
\end{tabular}

Please complete the following table if you answered (Yes) in B17.

\begin{tabular}{|c|c|c|c|}
\hline \multicolumn{2}{|c|}{ Question } & \multicolumn{2}{|c|}{ Answer } \\
\hline B18 & $\begin{array}{l}\text { What percentage of your academic staff falls within this category, } \\
\text { i.e. teach in programmes offered by companies within the country? }\end{array}$ & & \\
\hline B19 & How are they utilized e.g. regular time table, blocks, etc.? & & \\
\hline B20 & $\begin{array}{l}\text { Does your business school offer programs from companies outside } \\
\text { the country? }\end{array}$ & Yes & No \\
\hline
\end{tabular}

Please complete the following table if you answered (Yes) in B20.

\begin{tabular}{|l|l|l|}
\hline Question & Answer \\
\hline B21 & $\begin{array}{l}\text { What percentage of your academic staff falls within this category, } \\
\text { i.e., teach and programmes offered by companies from outside the } \\
\text { country? }\end{array}$ & \\
\hline B22 & How are they utilized e.g. regular time table, blocks, etc.? & \\
\hline
\end{tabular}




\section{Section C: Contribution of MBA programme}

In this section we would like to know about the contribution of your MBA programme in skills development.

\section{CIRCLE ONLY ONE NUMBER FOR EACH STATEMENT}

\begin{tabular}{|l|l|l|l|l|l|l|l|l|}
\hline C1 & Managerial skills & Inadequate & 1 & 2 & 3 & 4 & 5 & adequate \\
\hline C2 & Leadership skills & Inadequate & 1 & 2 & 3 & 4 & 5 & adequate \\
\hline C3 & Entrepreneurship skills & Inadequate & 1 & 2 & 3 & 4 & 5 & adequate \\
\hline C4 & Conceptual skills & Inadequate & 1 & 2 & 3 & 4 & 5 & adequate \\
\hline C5 & Communication skills & Inadequate & 1 & 2 & 3 & 4 & 5 & adequate \\
\hline C6 & Analytical skills & Inadequate & 1 & 2 & 3 & 4 & 5 & adequate \\
\hline C7 & Interpersonal skills & Inadequate & 1 & 2 & 3 & 4 & 5 & adequate \\
\hline C8 & Behavioural skills & Inadequate & 1 & 2 & 3 & 4 & 5 & adequate \\
\hline
\end{tabular}

\section{Section D: Strategic focus of the MBA programme}

Does your MBA programme have a special focus or niche? If so, how would you rate it using the following descriptors?

\begin{tabular}{|l|l|l|l|l|l|l|l|l|}
\hline D1 & Managerial skills & Inadequate & 1 & 2 & 3 & 4 & 5 & adequate \\
\hline D2 & Career development & Inadequate & 1 & 2 & 3 & 4 & 5 & adequate \\
\hline D3 & Business insight & Inadequate & 1 & 2 & 3 & 4 & 5 & adequate \\
\hline D4 & Economic benefits & Inadequate & 1 & 2 & 3 & 4 & 5 & adequate \\
\hline D5 & Employability & Inadequate & 1 & 2 & 3 & 4 & 5 & adequate \\
\hline D6 & Fulfilling life & Inadequate & 1 & 2 & 3 & 4 & 5 & adequate \\
\hline
\end{tabular}

Thank you very much for your participation

\section{Appendix 2 - Tables presenting the results}

Table 1: Mission statements of selected MBA business schools in South Africa

\begin{tabular}{|l|l|}
\hline Business school & Mission statement \\
\hline $\begin{array}{l}\text { Graduate School of } \\
\text { Leadership (UKZN) }\end{array}$ & $\begin{array}{l}\text { To educate managers and leaders to create value for society. } \\
\text { We are a school that is academically excellent, innovative } \\
\text { in research and critically engaged with society and its } \\
\text { institutions. }\end{array}$ \\
\hline $\begin{array}{l}\text { Gordon Institute of Business } \\
\text { Science }\end{array}$ & Connecting, excellence, building prosperity in Africa. \\
\hline MANCOSA & $\begin{array}{l}\text { To respond to the changing higher education demands of } \\
\text { both public and private sectors in emerging economies } \\
\text { through the provision of innovative education. }\end{array}$ \\
\hline Rhodes Business School & $\begin{array}{l}\text { To educate and influence responsible business practice } \\
\text { responsibly. }\end{array}$ \\
\hline Regent Business School & $\begin{array}{l}\text { To provide accessible, affordable business and management } \\
\text { education programmes for a developing world. }\end{array}$ \\
\hline $\begin{array}{l}\text { University of Stellenbosch } \\
\text { Business }\end{array}$ & $\begin{array}{l}\text { To produce leaders who can be employed at senior } \\
\text { management. }\end{array}$ \\
\hline $\begin{array}{l}\text { Graduate School of Business } \\
\text { \& Leadership (UNISA) }\end{array}$ & $\begin{array}{l}\text { Training and developing dynamic, ethical leaders for Africa } \\
\text { and globally, who value diversity and are educated to enhance } \\
\text { human prosperity on the African continent and globally. }\end{array}$ \\
\hline
\end{tabular}

Source: SABSA (2015) 
Table 2: MBA Programme outcomes

\begin{tabular}{|c|c|}
\hline Business school & Outcomes \\
\hline $\begin{array}{l}\text { Graduate School of Business } \\
\text { (UCT) }\end{array}$ & $\begin{array}{l}\text { - Understand research skills and be able to manipulate } \\
\text { - Unantitative information, graphs and equations } \\
\text { descriptive, prescriptive and argumentative character } \\
\text { - Conduct independent research and produce written texts in } \\
\text { line with international standards } \\
\text { - Communicate verbally or in writing with professional } \\
\text { audiences } \\
\text { - Challenge orthodoxies and redefine existing knowledge, } \\
\text { while demonstrating an awareness of the nature of } \\
\text { knowledge in the field. }\end{array}$ \\
\hline $\begin{array}{l}\text { University of Stellenbosch } \\
\text { Business }\end{array}$ & $\begin{array}{l}\text { USB's MBA has been designed to turn managers, } \\
\text { professionals, specialists and entrepreneurs into responsible } \\
\text { leaders, expert decision makers, strategic thinkers, effective } \\
\text { communicators and stewards of society. }\end{array}$ \\
\hline Milpark Business School & $\begin{array}{l}\text { Southern Africa has a need for managers and business leaders } \\
\text { who can conduct business responsibly and successfully, not } \\
\text { only locally but also in the global marketplace. To address this } \\
\text { need, Milpark's MBA degree is a multidisciplinary programme } \\
\text { with a practical orientation that provides managers, } \\
\text { professionals and graduates with advanced management and } \\
\text { business leadership education. }\end{array}$ \\
\hline $\begin{array}{l}\text { Graduate School of Business } \\
\text { \& Leadership (UNISA) }\end{array}$ & $\begin{array}{l}\text { More than anything, an MBA is structured to turn a manager } \\
\text { into a holistic leader capable of steering an organization and } \\
\text { its people to success. The MBA gives you access to continue } \\
\text { your studies towards a DBL, providing you meet the admission } \\
\text { requirements of the DBL. }\end{array}$ \\
\hline Rhodes Business School & $\begin{array}{l}\text { The Rhodes Business School's essence is 'Leadership for } \\
\text { Sustainability' and hence leadership and sustainability } \\
\text { principles underline all subjects in the MBA curriculum. } \\
\text { Emphasis is placed on business continuity, as well as achieving } \\
\text { a balance between economic, social and environmental } \\
\text { sustainability (the Triple Bottom Line). }\end{array}$ \\
\hline NWU Business School & $\begin{array}{l}\text { The NWU Business School also offers the Post-graduate } \\
\text { Diploma in Management on a part-time basis as an alternative } \\
\text { route to get you to your MBA. The MBA qualification is } \\
\text { regarded as the flagship of business training worldwide and } \\
\text { at the NWU Business School we aim to provide just that, a } \\
\text { qualification that is accredited and will provide the tools to } \\
\text { succeed in the business environment. }\end{array}$ \\
\hline
\end{tabular}




\section{Table 3: Institutional data}

\begin{tabular}{|c|c|}
\hline Business schools profile & $\begin{array}{l}\text { The top-ranked business schools; the Graduate Business School } \\
\text { (UCT) has been in existence for over } 50 \text { years, while the Gordon } \\
\text { Institute of Business Science opened in 2000. Using 2004, a year of } \\
\text { the review and re-accreditation of the MBA programme in South } \\
\text { Africa, as the base year, all } 17 \text { institutions have been offering the } \\
\text { MBA programme for the past } 13 \text { years. }\end{array}$ \\
\hline Ratings and rankings & $\begin{array}{l}\text { - In 2017, no South African Business school offering MBA featured } \\
\text { in the top } 100 \text { of the prestigious Financial Times rankings. } \\
\text { - In 2016, Graduate School of Business (UCT) was no. } 76 \text { in the } \\
\text { Financial Times ranking, down from } 52 \text { in } 2015 . \\
\text { - In 2016, Gordon Institute of Business Science was ranked no. } 74 \\
\text { for executive MBA, up from } 87 \text { in } 2015 \text {. } \\
\text { - In 2017, Gordon Institute of Business Science was ranked no. } 87 \\
\text { for executive MBA, showing a downward trend. } \\
\text { - In 2016, Eduniversal ranked Graduate School of Business (UCT) } \\
\text { and University of Stellenbosch Business School nos } 1 \text { and } 2 \\
\text { respectively in Africa under the } 5 \text { Palmes category (Universal } \\
\text { Business School), Gordon Institute of Business Science and Wits } \\
\text { Business School were ranked under the } 4 \text { Palmes category (Top } \\
\text { Business Schools), Graduate School of Business \& Leadership } \\
\text { (UNISA), Rhodes Business School, NWU Business School, UFS, } \\
\text { NMU Business School, Graduate School of Leadership (UKZN) } \\
\text { and Turfloop Graduate School of Leadership were ranked under } \\
\text { the } 3 \text { Palmes (Excellent Business Schools), Henley, MANCOSA, } \\
\text { Regent and Milpark Business School were in the } 2 \text { Palmes } \\
\text { League (Good Business Schools), Regenesys Business School } \\
\text { and Tshwane University of Technology Business School were in } \\
\text { the } 1 \text { Palme league (Local reference). } \\
\text { - Professional Market Research is another emerging MBA-ranking } \\
\text { body in South Africa. } \\
\text { There is a multiplicity of rankings based on delivery mode, such } \\
\text { as full time and online, for example. }\end{array}$ \\
\hline $\begin{array}{l}\text { Admission } \\
\text { requirements }\end{array}$ & $\begin{array}{l}\text { The admission requirements for the MBA programme are in line } \\
\text { with the SABSA (2012) guidelines as follows: } \\
\text { - Passing the Graduate Management Admission Test (GMAT) or } \\
\text { an entrance examination set by the business school. } \\
\text { - A four-year Bachelor degree, or a postgraduate Diploma in } \\
\text { Business Administration NQF Level } 8 \text { or an applicable Honours } \\
\text { degree. } \\
\text { - Recognition of prior learning (students should constitute at least } \\
10 \text { per cent of the total enrolment). } \\
\text { - Three to four years' working experience (comprehensive CV } \\
\text { required). } \\
\text { - Students should be } 25 \text { years of age and above. } \\
\text { - Proficiency in English for international students. }\end{array}$ \\
\hline Management \& staffing & $\begin{array}{l}\text { In all } 17 \text { business schools the MBA programme is coordinated by } \\
\text { the Dean and lecturers with industry experience. }\end{array}$ \\
\hline Student body & $\begin{array}{l}\text { The majority of students are South Africans and international } \\
\text { students from the Southern African Development Community } \\
\text { (SADC) and Asian countries. }\end{array}$ \\
\hline
\end{tabular}




\begin{tabular}{|c|c|}
\hline${ }^{\star \star}$ Fee structure & $\begin{array}{l}\text { - There is a variation in the student fee structure for South African, } \\
\text { SADC, other African countries and other countries owing to } \\
\text { international levies. } \\
\text { - Application fee range of R220-R3,000. } \\
\text { - Registration fee R4,500-R15,000. } \\
\text { - Total tuition fee per year R70,000-R264,500. } \\
\text { - Administration fees international students R5,000 } \\
\text { - Global module fee US } \$ 4,500-\$ 6,820 \text {. } \\
\text { - Core module fee R6,457 (for module based pricing). } \\
\text { - Elective module fee R6,457 (for module based pricing). } \\
\text { - International study tour R5,500 (vary with exchange rate and } \\
\text { - countries visited). }\end{array}$ \\
\hline Funding & $\begin{array}{l}\text { - Parent University or company (for private business schools). } \\
\text { - Tuition driven. } \\
\text { - Executive education (short learning programmes). } \\
\text { - Specialist research centres. } \\
\text { - Publications. } \\
\text { - Grants, donations, fellowships and scholarships. }\end{array}$ \\
\hline Assessment criteria & Continuous and summative assessment. \\
\hline
\end{tabular}

** Owing to the favourable exchange rate, the price structure of South African MBAs is regarded as competitive when compared with overseas business schools.

Table 4: Membership, accreditations and affiliations

\begin{tabular}{|l|l|l|l|l|l|l|l|}
\hline \multirow{2}{*}{ Business School } & \multicolumn{9}{l|}{ Membership and affiliations } \\
\cline { 2 - 8 } & SABSA & AABS & AMBA & AACSB & EQUIS & ABIS & PRME \\
\hline $\begin{array}{l}\text { Graduate School of Business } \\
\text { (UCT) }\end{array}$ & $Y$ & $Y$ & $Y$ & $Y$ & $Y$ & - & - \\
\hline UFS Business School & $Y$ & $Y$ & $Y$ & - & - & - & - \\
\hline $\begin{array}{l}\text { Gordon Institute of Business } \\
\text { Science }\end{array}$ & $Y$ & $Y$ & $Y$ & $Y$ & $Y$ & $Y$ & $Y$ \\
\hline Henley Business School & $Y$ & $Y$ & $Y$ & $Y$ & $Y$ & - & - \\
\hline $\begin{array}{l}\text { Graduate School of Business \& } \\
\text { Leadership (UNISA) }\end{array}$ & $Y$ & $Y$ & - & - & - & - & - \\
\hline $\begin{array}{l}\text { Turfloop Graduate School of } \\
\text { Leadership }\end{array}$ & $Y$ & $Y$ & N & - & - & - & - \\
\hline $\begin{array}{l}\text { Graduate School of Leadership } \\
\text { (UKZN) }\end{array}$ & $Y$ & $Y$ & - & - & - & - & - \\
\hline MANCOSA & $Y$ & $Y$ & - & - & - & - & - \\
\hline NMMU Business School & $Y$ & $Y$ & $Y$ & - & - & - & $Y$ \\
\hline NWU Business School & $Y$ & $Y$ & $Y$ & - & - & - & - \\
\hline Milpark Business School & $Y$ & $Y$ & - & - & - & - & $Y$ \\
\hline Regent Business School & $Y$ & $Y$ & - & - & - & - & - \\
\hline Regenesys Business School & $Y$ & $Y$ & - & - & - & & - \\
\hline Rhodes Business School & $Y$ & $Y$ & $Y$ & - & - & - & $Y$ \\
\hline $\begin{array}{l}\text { University of Stellenbosch } \\
\text { Business School }\end{array}$ & $Y$ & $Y$ & $Y$ & $Y$ & $Y$ & - & - \\
\hline Wits Business School & $Y$ & $Y$ & $Y$ & - & - & - & - \\
\hline $\begin{array}{l}\text { Tshwane University of Technology } \\
\text { Business School }\end{array}$ & $Y$ & $Y$ & Y & - & - & - & - \\
\hline
\end{tabular}

Key: SABSA = South African Business Schools Association. AABS =Association of African Business Schools, AMBA = Association of MBAs, AACSB = Association to Advance Collegiate Schools of Business, EQUIS = European Quality Improvement System, ABIS = Academy of Business in Society, PRME= Principles for Responsible Management Education. 
Table 5: Business schools qualification mix

\begin{tabular}{|c|c|}
\hline Business School & Qualification mix \\
\hline Graduate School of Business (UCT) & MBA, EMBA, PDBA, AIM \\
\hline UFS Business School & MBA General \\
\hline Gordon Institute of Business Science & MBA, PDBA, DBA, PMD \\
\hline Henley Business School & MBA \\
\hline $\begin{array}{l}\text { Graduate School of Business \& Leadership } \\
\text { (UNISA) }\end{array}$ & MBA \& MBL \\
\hline Turfloop Graduate School of Leadership & MBA General \\
\hline Graduate School of Leadership (UKZN) & MBA \\
\hline MANCOSA & $\begin{array}{l}\text { MBA General, MBA Tourism Management \& } \\
\text { Development }\end{array}$ \\
\hline NMMU Business School & MBA \\
\hline NWU Business School & MBA, PGDip in Management \\
\hline Milpark Business School & MBA, PGDBA, BBA \\
\hline Regent Business School & $\begin{array}{l}\text { MBA, PG Dip in Educational Management \& } \\
\text { Leadership, PGDip in Management, Honors } \\
\text { BCOM, BCOM, Dip Financial Management, } \\
\text { Dip Human Resource Management }\end{array}$ \\
\hline Regenesys Business School & $\begin{array}{l}\text { MBA, MBA (D/L), MPM, PDM, PDPM, CBM, } \\
\text { HCBM, CPM, BBA }\end{array}$ \\
\hline Rhodes Business School & MBA, PDEM \\
\hline University of Stellenbosch Business School & MBA, MDevFin, PhD \\
\hline Wits Business School & MBA, MAPP, PDM \\
\hline $\begin{array}{l}\text { Tshwane University of Technology Business } \\
\text { School }\end{array}$ & $\begin{array}{l}\text { MBA, Mtech Organization \& Leadership, } \\
\text { Dtech. Organization \& Leadership, Dtech } \\
\text { Business }\end{array}$ \\
\hline
\end{tabular}

Table 6: Mode of delivery

\begin{tabular}{|c|c|c|c|c|c|c|}
\hline \multirow[t]{2}{*}{ Business school } & \multicolumn{6}{|c|}{ Mode of lecture delivery } \\
\hline & $\begin{array}{l}\text { Full } \\
\text { time }\end{array}$ & $\begin{array}{l}\text { Part- } \\
\text { time }\end{array}$ & Modular & $\begin{array}{l}\text { Block } \\
\text { release }\end{array}$ & Online & $\begin{array}{l}\text { Distance } \\
\text { learning }\end{array}$ \\
\hline Graduate School of Business (UCT) & $\mathrm{Y}$ & $\mathrm{Y}$ & - & $\mathrm{Y}$ & - & - \\
\hline UFS Business School & - & $\mathrm{Y}$ & $\mathrm{Y}$ & - & - & - \\
\hline $\begin{array}{l}\text { Gordon Institute of Business Science } \\
\text { University }\end{array}$ & - & Y & Y & Y & - & - \\
\hline Henley Business School & - & - & - & - & - & - \\
\hline $\begin{array}{l}\text { Graduate School of Business \& } \\
\text { Leadership (UNISA) }\end{array}$ & - & Y & - & Y & - & - \\
\hline $\begin{array}{l}\text { Turfloop Graduate School of } \\
\text { Leadership }\end{array}$ & - & - & - & Y & - & - \\
\hline Graduate School of Leadership & - & - & - & - & - & Y \\
\hline $\begin{array}{l}\text { Management College of Southern } \\
\text { Africa }\end{array}$ & - & - & - & - & - & Y \\
\hline NMMU Business School & - & Y & - & Y & - & - \\
\hline NWU Business School & - & $\mathrm{Y}$ & - & - & - & - \\
\hline Milpark Business School & Y & Y & - & - & $\mathrm{Y}$ & Y \\
\hline Regent Business School & - & - & - & - & - & $\mathrm{Y}$ \\
\hline Regenesys Business School & - & $\mathrm{Y}$ & - & - & - & - \\
\hline
\end{tabular}




\begin{tabular}{|l|l|l|l|l|l|l|}
\hline \multirow{2}{*}{ Business school } & \multicolumn{7}{|c|}{ Mode of lecture delivery } \\
\cline { 2 - 8 } & $\begin{array}{l}\text { Full } \\
\text { time }\end{array}$ & $\begin{array}{l}\text { Part- } \\
\text { time }\end{array}$ & Modular & $\begin{array}{l}\text { Block } \\
\text { release }\end{array}$ & Online & $\begin{array}{l}\text { Distance } \\
\text { learning }\end{array}$ \\
\hline Rhodes Business School & Y & Y & Y & Y & - & - \\
\hline $\begin{array}{l}\text { University of Stellenbosch Business } \\
\text { School }\end{array}$ & Y & - & Y & - & - & - \\
\hline Wits Business School & Y & Y & - & - & - & - \\
\hline $\begin{array}{l}\text { Tshwane University of Technology } \\
\text { Business School }\end{array}$ & - & Y & - & - & - & - \\
\hline
\end{tabular}

Source: Furlonger (2017).

Table 7: MBA core curriculum of South African Business Schools

\begin{tabular}{|c|c|c|}
\hline Theme / category & Course/modules & $\%$ \\
\hline \multirow[t]{5}{*}{ Functional } & Strategic marketing/marketing management & 100 \\
\hline & Corporate strategy & 100 \\
\hline & Operations management/strategic operations & 69 \\
\hline & Human resource management & 44 \\
\hline & Supply chain management & 6 \\
\hline \multirow[t]{8}{*}{ Analytical skills } & Analytical methods & 6 \\
\hline & Business research methods/managerial statistics & 63 \\
\hline & Business conditions analysis & 12 \\
\hline & Research project/research methodology & 94 \\
\hline & Data analysis and decision-making & 18 \\
\hline & Management accounting and finance & 100 \\
\hline & Managerial economics & 75 \\
\hline & Information management & 56 \\
\hline \multirow[t]{8}{*}{ Soft skills } & Leadership & 44 \\
\hline & Change management & 43 \\
\hline & Organizational behaviour & 44 \\
\hline & Personal development & 13 \\
\hline & People management/human capital management & 43 \\
\hline & Entrepreneurship & 18 \\
\hline & Business communication & 12 \\
\hline & Project management & 6 \\
\hline \multirow[t]{3}{*}{ Sustainability } & Corporate governance, ethics and business law & 50 \\
\hline & Social responsibility/managing society and future & 50 \\
\hline & Values based leadership & 13 \\
\hline \multirow[t]{2}{*}{ Global perspective } & International business & 50 \\
\hline & Emerging markets & 12 \\
\hline
\end{tabular}


Table 8: Electives offered by South African business schools

\begin{tabular}{|c|c|}
\hline Business school & Electives \\
\hline UFS Business School & $\begin{array}{l}\text { Digital Marketing, Investment and Portfolio Analysis, } \\
\text { Project Management, Social Entrepreneurship, Risk } \\
\text { Management, International Business }\end{array}$ \\
\hline Wits Business School & $\begin{array}{l}\text { Dynamic Economies and Innovation, Managing for } \\
\text { Sustainability, Finance, General Management, Leading } \\
\text { Organizations in Complex Environments }\end{array}$ \\
\hline MANCOSA & $\begin{array}{l}\text { - Project Management, Entrepreneurship, Healthcare } \\
\text { Management, Leadership } \\
\text { - Supply Chain Management, Environmental } \\
\text { Management, Change Management }\end{array}$ \\
\hline $\begin{array}{l}\text { University of Stellenbosch } \\
\text { Business School }\end{array}$ & $\begin{array}{l}\text { - Decision Sciences, Entrepreneurship and Innovation, } \\
\text { Ethics and Sustainability, Finance and Economics } \\
\text { - Human Resources and Leadership, Information and } \\
\text { Technology, Management, Marketing Management } \\
\text { - Operations and Project Management, Strategic } \\
\text { Management }\end{array}$ \\
\hline $\begin{array}{l}\text { Graduate School of Leadership } \\
(\text { UKZN) }\end{array}$ & $\begin{array}{l}\text { Business, Governments and Society, Innovation } \\
\text { and Entrepreneurship, Investment and Portfolio } \\
\text { Management, Management Information Systems, } \\
\text { Strategic Marketing, International Business and } \\
\text { Finance, Coaching and Mentoring }\end{array}$ \\
\hline UCT & $\begin{array}{l}\text { - Advanced Leadership } \\
\text { - Applied Sustainable Responsible Investment } \\
\text { - } \text { Business Development in Emerging Markets } \\
\text { - Chanital Flows and Emerging Markets } \\
\text { - Coaching } \\
\text { - Company Valuations } \\
\text { - Complexity Organizations and Learning } \\
\text { - Customer Relationship Marketing } \\
\text { - E-marketing } \\
\text { - Doing Business in China and Asia } \\
\text { - Emerging Enterprises Consulting } \\
\text { - Financial Modelling } \\
\text { - Introduction to Legal Compliance } \\
\text { - Management Control Systems } \\
\text { - Modern Finance - Theory and Policy }\end{array}$ \\
\hline Rhodes Business School & $\begin{array}{l}\text { Project Management, Sustainability Law, Environmental } \\
\text { Economics, Climate Change and Business }\end{array}$ \\
\hline $\begin{array}{l}\text { Graduate School of Business \& } \\
\text { Leadership (UNISA) }\end{array}$ & $\begin{array}{l}\text { - Applied Business Informatics } \\
\text { - Strategic Project Management } \\
\text { - Financial Reporting and Analysis } \\
\text { - Strategic Supply Chain Management } \\
\text { - Operations Management } \\
\text { - Strategic Sustainable Marketing } \\
\text { - Strategy in a Global Context } \\
\text { - Advanced Labour Law } \\
\text { - Business Research }\end{array}$ \\
\hline Milpark Business School & $\begin{array}{l}\text { - Entrepreneurship and Innovation } \\
\text { - Business in Emerging Markets }\end{array}$ \\
\hline
\end{tabular}




\section{Table 9: Resource centres}

\begin{tabular}{|l|l|}
\hline Business school & Resource centres \\
\hline Gordon Institute of Business Science (GIBS) & $\begin{array}{l}\text { Centre for Leadership and Dialogue, } \\
\text { Centre for Research and Analysis, Centre } \\
\text { for Dynamic Markets, Centre for Japanese } \\
\text { Studies. }\end{array}$ \\
\hline Graduate School of Business (UCT) & $\begin{array}{l}\text { The Southern Africa-United States Centre for } \\
\text { Leadership and Public Values, UCT Centre for } \\
\text { Innovation and Entrepreneurship, Centre for } \\
\text { Coaching }\end{array}$ \\
\hline $\begin{array}{l}\text { University of Stellenbosch Business School } \\
\text { (USB) }\end{array}$ & $\begin{array}{l}\text { Centre for Leadership Studies, Africa Centre } \\
\text { for Investment Analysis. }\end{array}$ \\
\hline WITS Business School & WBS Case Writing Centre \\
\hline School of Business Leadership (UNISA) & Centre for Corporate Citizenship \\
\hline UFS Business School & The Centre for Business Dynamics \\
\hline
\end{tabular}

